\title{
MANAGEMENT OF NATURAL RESOURCES ON THE JUST BASIS: A Study on Empowered Authority for Coastal Villages in Using Natural Resources along the Coastal Areas in Banyuwangi, Indonesia.
}

\author{
${ }^{1}$ Nurul Fajri Chikmawati \\ Faculty of Law, Universitas Indonesia \\ Jakarta, Indonesia \\ nurulfajri2008@yahoo.com
}

\author{
${ }^{2}$ Tri Hayati \\ Faculty of Law, Universitas Indonesia \\ Jakarta, Indonesia \\ tri_hariri@yahoo.com
}

\begin{abstract}
Villages along the coastal areas in Indonesia have been sociologically inseparable parts of fishing communities inhibiting within the vicinity. They serve not only as dwelling places but also as the source on which the dwellers substantially dependent. Despite the abundant resources available, the fishermen do not seem to prosper. The development programs mainly aimed at economic growth will encourage the government to intensify the natural resource exploration to finance the programs. The spirit to promote regional autonomy should result in bigger roles of the local governments to participate in their autonomously managing their own natural resources. The Law of Republic Indonesia No 6 of 2014 on Villages has not specifically defined the authority to manage the natural resources along the coastal areas as stipulated in The Law of Republic Indonesia No 23 of 2014 on Local Government. With socio-juridical approach, the data of this research was collected from Subdistrict of Muncar, Banyuwangi District. The issues on the matter in Muncar are normatively highlighted to generate recommendations to improve both the institutions and the capacity of resources available to better formulate the operational guidelines.
\end{abstract}

Keywords-Village; Coastal Village; Natural Resources; Regional Autonomy; Decentralization.

\section{INTRODUCTION}

Indonesia is an archipelagic state1 with thousands of coastal villages 2 within the existing islands from Sabang to Merauke. The existence of these villages has been sociologically recognized long before the proclamation of independence of
Indonesia3. They have occupied the coastal areas by utilizing the existing marine fishery resources4. Historically, their existence has also been recognized by the Dutch colonial government by granting the right to benefit economically on the marine fishery resources, especially in the field of shipping and capture fisheries5. When Indonesia gained independence in 1945, then as a free nation, all the natural resources in the territories of Indonesia, including coastal and marine natural resources belong to 6 Indonesian people and the state has authority with a right called the State's Right to Control7. As the concept of welfare state 8 , the state does not only act as night watchman as advocated by Classical Liberalists in the 19th century, but also plays an important role in the achievement of welfare with the authority provided by law to provide public facilities and manage natural resources for the greatest prosperity of people9.

Basically, the management of natural resources in the earth, water and space is the authority of the state on the basis of the state's right to control10 as mandated in Article 33 Paragraph (3) of the 1945 Constitution in which the implementation can be authorized to autonomous areas and customary law communities in accordance with the requirements and not against the national interest. The authority in the management of natural resources is granted by the state to the autonomous areas and customary law communities based on the the prevailing laws as stipulated in the Law of the Republic of Indonesia No. 5 of 1960 on Agrarian Principles.

The concept of natural resources is national wealth at the highest level, Article 33 of the 1945 Constitution grants the authority to the State as an 
organization of people's power to utilize natural resources in order to achieve the greatest prosperity of the people in the context of nation and state.11The authority granted to the state for the management of natural resources includes aquatic resources. This does not mean that the status of natural resources of this water becomes fully state property as the state property concept provides full authority to the state in resource management based on ownership and control over its utilization. However, individual and group may be authorized to manage and take advantage of these resources in accordance with applicable law provisions. This indicates that in principle, the management of natural resources is the authority of the state, but in practice, the state may grant such authority to local governments (autonomous areas) or customary law community based on the principle of decentralization.

Basically, decentralization is applied in order to make room for participation in decision making12. Decentralized governance affects the authority of coastal and and marine13 natural resources management14. Article 27 of Law No. 23 of 2014 on Regional Government specifically regulates the authority of the Provincial Government which is characterized by the archipelago and marine areas to manage coastal and marine natural resources up to 12 nautical miles calculated from the coastline to water territory. Likewise, Regency/Municipality Government as the producer of coastal and marine natural resources shall be granted the authority to benefit up to a maximum of 4 nautical miles. Meanwhile, village government granted authority by law autonomously to regulate and manage its territories, including assets and the economic, social and cultural resources that have been possessed from generation to generation becomes unclear.

It is ironic that the law has removed the coastal and marine natural resources which are the mainstays of coastal villages to meet their life needs from social spaces. The coastal villages of Indonesia, which seem to be not spaced by coastal areas, are now structurally and systematically marginalized groups. The real condition of Indonesia's coastal villages currently needs serious attention 15 , given that the villages have lagged far back several decades than other regions, especially urban areas16. It is characterized by marine and fishery development policy during the New Order regime that did not take side the coastal communities, especially fishermen17. Likewise, post-reform government did not totally support the fishermen. As a result, coastal villages turned into enclaves of poverty, underdevelopment and lag18. According to Arif Satria, one way to prosper the fishermen can be performed by granting the right to access marine natural resources and the recognition of the right of marine natural resources management. Both of these rights have been owned by the coastal communities for generations, including coastal communities in Banyuwangi Regency, East Java. This paper is partly the result of research conducted in Muncar Sub-District, Banyuwangi Regency, East Java Province from July to December, 2016. As one of the regencies producing fishery and marine commodities in East Java province, Banyuwangi Regency also has economic potential in the marine tourism sector managed by Banyuwangi communities and is strongly supported by various parties, including Local Government and business world. Banyuwangi coastal villages that are geographically closest to coastal and marine areas should be able to take more roles based on the authority granted by law. The problem is that how the villages, in this case is the coastal villages in Muncar Sub-District Banyuwangi Regency, use their authority to optimize the utilization of coastal resources for various activities based on coastal natural resources to improve the welfare of the villagers. This research is performed using empirical law research method to obtain the real condition in societal setting in Muncar sub-district, especially in the coastal villages.

\section{LITERATURE REVIEW}

In political and law philosophies, the idea of authority presents a set of issues regarding the justification of government and corresponding obligations of citizens, especially the obligation of citizens to obey the law19. Authority or formal power is a power derived from legislative power (granted by law) or by administrative executive power20. The government in its capacity as ruler who organizes the public interest must be based on the authority obtained from the legislative authority as a form of control21. The nature of authority is essentially always bound to a certain time, subject to pre-determined limits and is bound to written and unwritten law (principles of good governance) 22 . This is also the case with the authority of the village. Village authority includes village administration, implementation of village development and community development based on community 
initiatives, right of origin and village customs. The implementation of village authority based on the Right of Origin and village-scale local authority is governed by the village. While the authority assigned by the Central Government, Provincial Government or Regency/Municipality Government and other authorities assigned to the village shall be accompanied by a budget for such activities.

According to the Law of the Republic of Indonesia No. 6 of 2014, village shall be village (Official Village) and traditional village or as referred to by other names, hereinafter referred to as Village, shall be a unit of community that has boundaries with the authority to regulate and manage the affairs of government, interests of the local communities based on the community's initiatives, right of origin, and/or traditional right recognized and respected in the system of government of the Republic Indonesia.

Thus, the village in addition to having authority based on Law No. 6 of 2014 as a written law, it may also have authority based on unwritten law which has been handed down from generation to generation known as local wisdom accommodated within the scope of the Right of Origin. The meaning of right of origin shall be a right that shall be a legacy that shall be still alive and initiative of the Village or Village community in accordance with the development of the community life, among others organizational systems of indigenous peoples, institutions, organization and customary law, Village treasury land, as well as agreement in the Village community life. From this right of origin, the villages can at least organize indigenous peoples' organizational system, foster community institutions, foster customary institutions and laws, manage village treasury land and develop roles of village communities. With village-scale local authority, a village can organize various activities, such as managing boat moorings, village markets, public baths, irrigation networks, rural neighborhoods, fostering the health of rural communities and organizing integrated service posts (Posyandu), developing and fostering art and learning centers, managing libraries, managing village retention basins, managing village-scale drinking water and building village roads.

Based on the right of origin and village-scale local authority, a coastal village can at least organize activities limitatively stated in the law. However, the law does not limit village activities based on the authority owned only to the extent of these details. Thus, the authority based on the right of origin of a village can trace the rights owned and is implemented continuously and not contrary to the prevailing laws and regulations.

In the management of coastal natural resources, a concept known as Integrated Coastal Management (hereinafter abbreviated as ICM) was introduced to the world through the provision of Chapter 17 in Agenda 21 which later became a reference by the United Nation Conference on Enviroment and Development (UNCED) and was discussed deeply in Earth Summit, in June 1992 in Rio de Janeiro, Brazil. Biliana Cicin-Sain and Robert W. Knecht provide an explanation of the management of integrated coastal areas as a dynamic and continuous process developed for the sustainable use, development and protection of coastal and marine resources. The process is primarily designed to combine between the sectoral management approach and governmental authority from a variety of different levels related to coastal areas23. This process is performed by ensuring that policies in all sectors (for example, fisheries, oil and gas and clean water) at all levels of government have been in accordance and consistent with coastal policies at the national level.

According to Biliana Cicin-Sain and Robert W. Knecht, there are at least 5 (five) components that must be integrated in coastal area management, namely24: Intersectoral Integration, is a horizontal integration effort between different coastal and marine sectors in coastal area management, such as fisheries, construction of oil and gas facilities, marine tourism, marine mammal conservation and port development sectors. In addition, the integration is performed vertically, namely between development in coastal and marine areas and the existing development in the mainland, such as fish cultivation, forestry and mining sectors. This integration is performed to avoid conflict between government institutions. Intergovermental Integration, is a policy integration at all levels of government, from the central government to the village government. This is intended to avoid any differences in perceptions both at the policy level and implementation level. Spatial Integration, is the integration of existing activities in the coastal areas with existing areas in the sea and in the land. Conditions that occur in the land will affect the existing ecosystem in the sea and vice versa. For example, fish production is strongly affected by sea 
water quality. While the quality of sea water is also strongly affected by pollutants flowing from land to sea. Science-management Integration, the coastal area management requires approaches from various sciences, such as natural, social and engineering science. This can be understood because the problems in the coastal areas require a variety of scientific approaches so that all the existing potentials can be managed properly. International Integration, is an integration of inter-state interests that have adjacent coastal and marine areas. This is important related to the problem of over fishing, illegal fishing, pollution, border areas of inter-state waters and others.

As a follow up of the Indonesian government commitment to the implementation of Agenda 21 of the Rio de Janeiro Earth Summit in 1992, Integrated Coastal Management (ICM) approach appeared in Indonesian Agenda 21. Apparently, ICM in Indonesia is relatively and insufficiently 25 implemented in the management of natural resources in coastal areas, while the development process in this sector continues to be implemented massively in some areas in Indonesia. Policies and strategies in the development of marine resources based on ICM are the result of the political process through the stages of negotiation of interests among various stakeholders. Therefore, its success also depends on commitment and willingness of stakeholders.26 Law No. 27 of 2007 concerning the Management of Coastal Areas and Small Islands, as stated in the provision of the elucidation of the law embraces the ICM approach as the legal basis for the implementation and management of coastal natural resources in Indonesia. The objectives of the management of coastal areas (and small islands) in Law No. 27 of 2007 on the Management of Coastal Areas and Small Islands are:

a. Protecting and conserving, rehabilitating, utilizing, and enriching coastal resources and small islands as well as the ecological system sustainably;

b. Creating harmony and synergy between Government and Local Government in the management of coastal resources and small islands.

c. Strengthening the participation of communities and government agencies as well as encouraging community initiatives in the management of coastal resources and small islands to achieve justice, balance, and sustainability, and;

d. Improving social, economic, and cultural values of the community through community participation in the utilization of coastal resources and small islands.

Thus, the law provides space for government and community to participate in the management of natural resources in coastal areas. Community, in this case is local community, traditional community, and customary law community are key stakeholders in the utilization of coastal natural resources in which their interests must be considered.

\section{RESULT AND DISCUSSION}

Geographically, Banyuwangi Regency is one of the regencies in East Java province located at easternmost end of Java Island. Banyuwangi Regency is bordered by Situbondo Regency in the north, in the east is bordered by Bali strait, in the south is bordered by Indonesian Ocean, and in the west is bordered directly by Jember and Bondowoso Regency. Banyuwangi Regency has an area of 5,782.50 square $\mathrm{km}$, consisting of land and water areas. The land area of Banyuwangi Regency consists of highland in the form of mountains, which is an area producing commodities of plantation and lowland as an area producing various agricultural commodities. The east to the south side is a coastal area along $175.8 \mathrm{~km}$ as fish and other marine biota producing area. With the stretch of the coast, the development of fisheries and marine sector through intensification and diversification efforts 27 are expected to increase the contribution of marine fisheries commodities and other sectors, such as tourism to increase local and national revenue.

Banyuwangi Regency has 24 sub-districts and each sub-district consists of several villages consisting of several hamlets or neighborhoods to Rukun Tetangga (RT) and Rukun Warga (RW) levels. Overall, there are 217 villages, 2,839 RWs and 10,569 RTs.28 The sub-districts with coastal areas are Pesanggaran, Purwoharjo, Tegaldlimo, Muncar, Rogojampi, Kabat, Banyuwangi, Kalipuro, Bangorejo, Siliragung and Wongsorejo sub-districts. 
In general, the population of Banyuwangi Regency is predominantly Muslim, followed by Hinduism and other religions. In addition, there are indigenous communities, such as coastal community, indigenous community and agrarian community29. Coastal community is a group of people who still hold customs and local traditions, especially in the coastal area of Banyuwangi, such as in Rajegwesi, Puwoharjo, Muncar coastal areas and so on. The indigenous people of Banyuwangi are known by Osing community 30 .

Several economic potentials particularly related to the utilization of natural resources in coastal areas in Banyuwangi are utilized for capture fishery business and marine aquaculture; coastal nature tourism, fish processing, water transportation; sand and minerals extraction. Fishing business in the form of capture fishery, fish farming (ponds); floating net cages and seaweed cultivation. This fishery business is almost equally conducted in the coastal villages of Banyuwangi. However, the majority of fishery businesses are concentrated in the villages of Muncar sub-district.

Banyuwangi Regency also develops its tourism potentials, such as culture, religion, and marinebased tourism. Several beach tourist attractions have been developed by involving various components of community. Tourism Office of Banyuwangi Regency is working hard to invite stakeholders in the field of tourism to synergize to develop tourism of Banyuwangi to be more advanced and the result can be enjoyed by the community directly.31Banyuwangi has mainstay areas to develop its tourism potential. The mainstay areas are known as the "diamond triangle".

Banyuwangi Regency has 9 to 11 coastal subdistricts that serve as the fishery mainstay areas. The fish processing industry is concentrated in Muncar Sub-District. There are more than 70 fish processing industries with various scales, from home industry to large industries scale that have been able to export to various countries, such as to several countries in Asia, Europe and US. Some other sub-districts are also functioned for fish processing business, such as in Wongsorejo, Kalipuro and Pesanggaran sub-districts in the south. These fish processing industries are located close to beach and fish landing areas. On the one hand, the existence of these industries provide jobs for the surrounding community, but on the other hand, these industries produce waste that can potentially pollute coastal waters.

There are two large ports in Banyuwangi Regency that serve the transportation of people and goods by sea, namely Tanjung Wangi Port and Ketapang Port. The Boom Beach Port is utilized to serve the freight transport by sea with small vessels to various regions in Indonesia. In addition, there are several sub-districts with coastal fishing ports located on the beach near the fish auction (TPI). The buildings and other facilities in the sea port utilize the space or coastal areas, including leaning ships and anchor facilities.

Types of mining businesses in Banyuwangi include metal and mineral mining, nonmetal mining, rock mining and geothermal mining. The mining business utilizing the coastal natural resources of Banyuwangi Regency is mineral mining business consisting of gold, silver, copper and iron sand. The areas that have been designated as gold, silver, copper metal mining with an area of 22,600 ha are located in Pesanggaran and Siliragung subdistricts. The areas for iron sand mining business spread along the coast, including Banyuwangi, Kabat, Rogojampi, Muncar, Purwoharjo, Siliragung and Pesanggaran sub-districts.

Spatial and territorial arrangements along with the utilization of natural resources potentials mentioned above have been proclaimed in Regional Regulation of Banyuwangi Regency No. 8 of 2012 on Spatial Planning of Banyuwangi Regency in 20122031 and Medium Term Development Plan of Banyuwangi Regency in 2016-2021.

\section{A. Strengthening the Authority of Coastal Village Community in Muncar Sub-District Banyuwangi}

Muncar sub-district is one the sub-districts in Banyuwangi Regency which covers 146.07 square $\mathrm{km}$, some of the areas are directly bordered by Bali Strait in the east. Along the coast of Muncar, there are villages with potential coastal resources that can be developed as marine fishery producing areas, both capture resources and aquaculture, processing of various fish products as well as marine tourism.

Based on the category of villages according to Law No. 6 of 2016, the existing villages are Official Villages. As Official Village, these villages have 
authority based on the right of origin, village-scale local authority, authority based on coadministration task from the Goverment, Provincial Government, and the duty of the Regency/Municipal Government.

The population in Muncar Sub-District has similar characteristics as the population inhabiting coastal areas. They have a heterogeneous family background, both the indigenous and immigrant population, mostly from areas around Banyuwangi, such as from the coastal regencies of East Java and from Madura or even from the Bugis tribe, South Sulawesi. They are partly from the families who work as fishermen and continue to work as fishermen, ship laborers, fish traders, fish processors or other jobs such as stall traders, fish processing industry workers and so forth.

There are supporting facilities in Muncar subdistrict, such as port or fish landing areas spreading over several villages, fish market, fish auction and minapolitan port which are highly representative for anchoring various types of ship from various areas of East Java. Fish processing companies are also built near the port. This is to facilitate in obtaining raw materials in the form of fresh fish from the sea entering the port of fish auction.

The coastal areas of Muncar sub-district, such as the beach and minapolitan port area, are public areas visited by the visitors from villages in Muncar sub-district and visitors from outside Muncar to enjoy the beauty of Muncar beach and sea scenery, and to see the activities of fishermen with traditional boats at the port. This is a good tourism potential to be developed and the development of this potential can be the authority of the village government as a village-scale local authority.

In recent years, the development of tourism potential in Banyuwangi regency is rapid. The citizens or community members are very enthusiastic in the initiative to explore the tourism potentials, especially marine tourism in the area. The regional government of Banyuwangi Regency is very supportive and welcomed the initiative of these community members by facilitating various needs needed to build tourist attractions. Furthermore, it needs to be regulated about the authority of the management of these tourist attractions.
The following table shows the distribution in management and activities on the coast of Muncar: Table 1: Fishery Facilities in Muncar SubDistrict

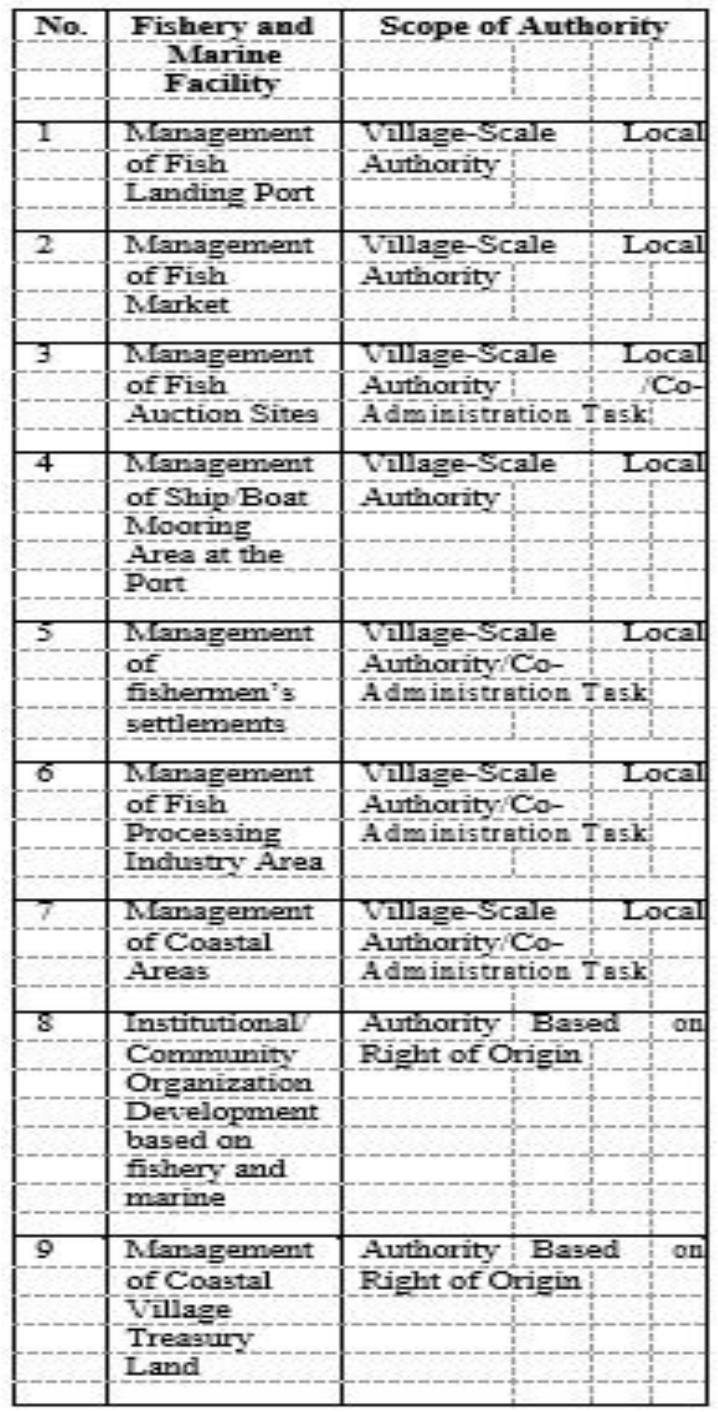

Law No. 6 of 2014 on Village and Government Regulation of the Republic of Indonesia No. 43 of 2014 on the implementation of Law No.6 of 2014 do not actually limit the extent of authority based on the right of origin and village-scale local authority. This is an opportunity for coastal villages, including coastal villages in Muncar sub-district to immediately identify and inventory facilities, assets and activities in the area. Table 2 shows some village activities and allocation of authority owned by the village so that it is expected that the villages can optimize their potential resources. 
The Government Regulation of the Republic of Indonesia No. 43 of 2014 on the Implementation of Law No. 6 of 2014 assigns Regency/Municipal Government along with the Village Government to identify and inventory facilities, assets, and activities conducted in the village to establish authority based on the right of origin and villagescale local authority. Furthermore, Regency/Municipal Government shall stipulate it in a regent/mayor regulation on the list of authorities concerned. This regent/mayor regulation will be a reference for the Village Government to enact it in village regulation on authority based on the right of origin and village-scale local authority in accordance with applicable laws and regulations. With the limited resources and capacity of the village, the local government can take the initiative to start identifying and invertorying the existing activities and resources for further processing. The involvement of all organizational and institutional elements in rural communities is necessary because in the field, there are communities that have managed some of the coastal natural resources for various purposes, such as aquaculture, tourism and nature consevation activities. This is important to ensure the legality of management and utilization in order to avoid problems and conflicts of authority in the future.

\section{CONCLUSION}

Decentralization has provided space for governments and communities to participate in the management of coastal natural resources. Communities who occupy coastal villages, including coastal villages in Muncar sub-district, are stakeholders whose interests must be taken into account. Law No. 6 Year 2014 about Villages empowering Villages to utilize coastal natural resources for businesses such as capture fisheries, tourism businesses, conservation, fish processing industries at various scales, settlement and transportation based on local village-level authority and origin rights. Based on these two authorities, the village no longer simply recommends business licensing applications, but participates and obtain benefits directly. To strengthen the authority, the village government with the district government inventory the existing authority to obtain legalization in the form of regents and village regulations to avoid conflicts of authority.

\section{ACKNOLEDGMENT}

We like to show our gratitude to the Universitas Indonesia for the support of this article by Grant PITTA 2017. The author thank to Dr. Tri Hayati,SH.,MH. as Doctoral Advisor also as second author.

\section{REFERENCES}

[1] Arif Satria," Ekologi Politik Nelayan", Yogyakarta: LKiS, 2009.

[2] Arif Satria, "Pengantar Sosiologi Masyarakat Pesisir",. Jakarta: Yayasan Penerbit Obor, 2015.

[3] Arif Satria, "Pesisir dan Laut Untuk Rakyat", Bogor: IPB Press, 2009.

[4] Banyuwangi Regency- Central Bureau of Statistics of Banyuwangi Regency, Banyuwangi in Figures 2016.

[5] Banyuwangi Regency, "Rencana Pembangunan Jangka Panjang Daerah Kabupaten Banyuwangi 2005-2015",

[6] Biliana Cicin-Sain and Robert W. Knecht," Integrated Coastal and Ocean Management: Concepts and Practices", Washington DC: Island Press, 1998.

[7] Didik G..Suharto, "Membangun Kemandirian Desa", (Yogyakarta: Pustaka Pelajar, 2016.

[8] Dina Sunyowati, "Tata Kelautan Berdasarkan Integrated Coastal Management pada Pembangunan Berkelanjutan", Pro Justitia Law Journal, April 2009, Volume 27, No. 1. p. 36

[9] Frank J.Goodnow, "A Study in Government: Politics and Administration", New Jersey: The Transaction Publishers, 2008.

[10] Hanif Nurcholis, "Pertumbuhan dan Penyelenggaraan Pemerintahan Desa". Jakarta: Erlangga Publisher, 2011

[11] Jesse C. Ribot, "Waiting For Democracy: The Politics of Choice in Natural Resource Decentralization",WashingtonDC:World Resources Institute, 2004.

[12] Ministry of Marine Affairs and Fisheries. Analisis Data Pokok Kelautan dan Perikanan. Jakarta: Center for Data, Statistics and Information, 2014.

[13] Pigoselpi Anas, "Membongkar Akar Kemiskinan Nelayan". Jakarta: Roda Bahari, 2015. 
[14] Republik Indonesia, Law of the Republic of Indonesia No. 5 of 1960 on Agrarian Principles.

[15] Republik Indonesia, Law of the Republic of Indonesia No. 23 of 2014 on Local Goverment.

[16] Republik Indonesia, Law of the Republic of Indonesia No. 6 of 2014 on Villages.

[17] Republic Indonesia, Law No. 5 of 1985 on EEZ.

[18] Rikardo Simarmata and Denny Karwur, "Tinjauan dan Contoh Peraturan Perundangundangan dalam Pengelolaan Pesisir di Daerah" in a book entitled "Menuju Harmonisasi Sistem Hukum Sebagai Pilar Pengelolaan Wilayah Pesisir Indonesia", Jakarta: Ministry of National Development Planning/BAPENAS, Ministry of Marine Affairs and Fisheries, Ministry of Law and Human Rights in collaboration with Mitra Pesisir, 2005.

[19] Rokhmin Dahuri. "Menuju Indonesia Sebagai Poros Maritim Dunia", Bogor: Roda Bahari, 2016.

[20] Sanford Levinson. "The Walfare State", in a book entitled "A Companion to Philosophy of Law and Legal Theory," Malden-USA: Blackwell Publishing, 2008.

[21] S.Prajudi Atmosudirjo, "Hukum Administrasi Negara", 10th Edition, Jakarta: Ghalia Indonesia, 1995.

[22] United Nations, United Nation Convension of The Law of The Sea (UNCLOS -1982)

[23] United Nation, The UN-General Assembly Resolution 1803 (XVII) of 14 December 1962, "Permanent Sovereignty over Natural Resources".

[24] Vincent A.Wellman, "Authority of Law," in his book entitled "A Companion to Philosophy of Law and Legal Theory". Malden-USA: Blackwell Publishing, 2008. 